\title{
What does the European Union Think about the USA, Russia, the PRC, Germany and Itself? - ERRATUM
}

\author{
MARCIN WOJCIECH SOLARZ, MA \\ WOJTASZCZYK, MACIEJ ZYCH and \\ ANNA M. SOLARZ
}

doi: https://doi.org/10.1017/S1062798719000413 Published by Cambridge University Press, 18 December 2019.

The Publisher apologises that upon publication of this paper the title and location of the grant were listed incorrectly within the Acknowledgment section, it should have read as below:

\section{Acknowledgement}

The maps accompanying the article were made as part of a project 'Atlas of Political Geography of Poland. Poland in the Contemporary World' financed by the National Science Centre, Poland. Grant No. 2014/15/B/HS5/00729. The atlas was published in Polish and English in 2018.

The survey results from the Gallup Inc. come from the library of Ohio State University, Columbus, OH, USA.

\section{Reference}

Solarz MW, Wojtaszczyk M, Zych M and Solarz AM (n.d.). What does the European Union Think about the USA, Russia, the PRC, Germany and Itself? European Review, 1-11. doi: 10.1017/S1062798719000413 